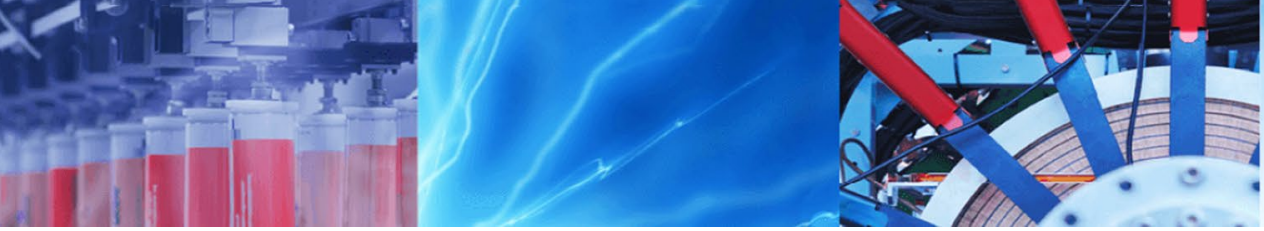

Research Article

\title{
Assessing the factors affecting the water chemistry parameters in the auxiliary water system of a nuclear power plant
}

\author{
Parasuraman Suganya ${ }^{1,3}$ ([) Ganapathiraman Swaminathan ${ }^{1}$ - Bhargavan Anoop ${ }^{2}$. G. V. R. R. S. G. Siva Prasad ${ }^{3}$. \\ Jaganathan Nagarajan ${ }^{3}$
}

Received: 17 July 2020 / Accepted: 13 October 2020 / Published online: 26 October 2020

(c) Springer Nature Switzerland AG 2020

\begin{abstract}
Cooling towers are used as a final heat sink which cools the reactor auxiliary systems and transfers the heat energy to the atmosphere. The reliability endowed upon the cooling tower operation in a nuclear power plant is considerably high when compared to other power plants since the proper functioning of auxiliary systems is crucial for the decay heat removal from the core. Hence, appropriate chemistry control is mandatory in the operation of cooling towers for corrosion control, scale prevention, and control of biological growth. The operating data and water chemistry parameters like conductivity, turbidity, free residual chlorine, $\mathrm{pH}$, cycles of concentration, chlorides, hardness, and alkalinity are analyzed for a typical nuclear power plant. The effect of the individual water quality parameter is correlated by the Pearson matrix to find its influence on the system water chemistry parameter. It is observed that the build-up of chloride ions in the cooling water is the major contributing factor for the cooling tower feed and bleed operations. The aspect of reducing the feed and bleed operation is analyzed, and suitable modifications are suggested to reduce water consumption.
\end{abstract}

Keyword Cooling tower - Blowdown · Water chemistry $\cdot$ Cooling water $\cdot$ Corrosion control $\cdot$ Water reduction

$\begin{array}{ll}\text { Abbreviations } \\ \text { CT } & \text { Cooling tower } \\ \text { TDS } & \text { Total dissolved solids } \\ \text { EC } & \text { Electrical conductivity } \\ \text { COC } & \text { Cycle of concentration } \\ \text { FRC } & \text { Free residual chlorine } \\ \text { M-alk } & \text { Methyl orange alkalinity } \\ \text { P-alk } & \text { Phenolphthalein alkalinity } \\ \text { LSI } & \text { Langelier saturation index } \\ \text { RSI } & \text { Ryznar stability index } \\ \text { Turb. } & \text { Turbidity } \\ \text { TH } & \text { Total hardness } \\ \text { CH } & \text { Calcium hardness } \\ \text { MH } & \text { Magnesium hardness }\end{array}$

Abbreviations

TDS

EC Total dissolved solids

Cycle of concentration

Free residual chlorine

M-alk Methyl orange alkalinity

P-alk Phenolphthalein alkalinity

LSI Langelier saturation index

RSI Ryznar stability index

Turb. Turbidity

$\mathrm{CH} \quad$ Calcium hardness

Magnesium hardness

\section{Introduction}

A typical nuclear power plant encompasses reactor core, reactor containment system, safety-related primary and secondary heat transport systems, conventional and steam-water systems, electrical and instrumentation systems, fuel handling, and radioactive waste management systems. Most of the components and instruments deployed in the above systems require cooling water systems for regular operation. Failure of cooling water system is critical and hence, is provided with Class: III power supply sourced from diesel generators to increase the availability of safety-related nuclear systems during normal and accident conditions [1]. Auxiliary cooling water systems are required for heat removal from safety-related components like compressors, safety-related unit coolers, nitrogen

Parasuraman Suganya, suganya_bhavini@igcar.gov.in | 'Department of Civil Engineering, National Institute of Technology, Tiruchirapalli, Tamilnadu, India. ${ }^{2}$ Indira Gandhi Centre for Atomic Research, Kalpakkam, India. ${ }^{3}$ PFBR Project, Bharatiya Nabhikiya Vidyut Nigam Limited, Kalpakkam 603102, India. 
systems which are essential for nuclear heat removal and reactor operations. The heat loads from cooling water are ultimately released to the atmosphere through cooling towers. The reliability of the system is the probability that it will meet the minimum performance requirement when called upon. The reliability of the cooling water system with respect to the chemistry aspect deals with the probabilities of not encountering the chemistry-related failures in the system so that it delivers its intended function. Failure mechanisms are symptoms of underlying influence factors like process conditions (water chemistry, temperature, pressure, flow), operational, and organizational factors. Reliability growth is increased by modifying these influence factors [2, 3]. Based on the operating experience of the nuclear power plant, the failure rate of the cooling tower to open is 28.4 per million hours which is a demand related failure condition unable to operate the necessary component to accomplish the intended function [4]. So it is imperative that maintaining the healthiness of cooling water systems is highly required for the safe operation of reactor systems whose unavailability will require the reactor to be shut down immediately. Apart from severe system failure, undesirable chemistry violations are immediately visible in operational parameters like temperature, pressure drops, efficiency, and system output. To avoid the catastrophic failure of the cooling water system, strict chemistry control, monitoring, and assessment of the systems should be regularly performed and logged as part of the preventive maintenance.

By practicing stringent guidelines with proper monitoring and assessment of water quality parameters, it is possible to increase the reliability of critical equipment and prevent the outages of power plants [5]. Proper chemical conditioning is a viable option to prevent and control the undesired phenomena in the water and steam cycle. The measurement and observation of slight variations in $\mathrm{pH}$ give the trend of chemistry-related damages $[6,7]$. To effectively control the scaling and corrosion products, the system should be sampled and analyzed for assessing the concentrations of control parameters at regular time intervals. The critical metrics for monitoring the physical properties of the system are by studying the system conditions like operating pressure, temperature, flow rate, and that for monitoring the chemical properties is by estimating the control parameters like $\mathrm{pH}$, conductivity, etc.[8-12]. The material degradation of carbon steel is mainly due to corrosion, wear, and cracking due to cyclic stresses or high mechanical loads. The major contributor is the aqueous corrosion of carbon steels in the form of general, crevice, pitting, galvanic, and deposit corrosion. The main factors involved in material degradation are the material constituents, water quality, and system operating conditions [13]. The operating state of the system, like temperature, pressure, and the flow rate, has influenced the system chemistry and material degradation property. For example, the rise in temperature increases the amount of carbonate scale. Turbulence in the system also promotes scale formation [13-15].The reliability of the chemistry control is highly improved after establishing immediate control over the source water chemistry analysis [16]. Most of the research has been extensively carried out in the field of corrosion, scaling, deposition rates, and its associated phenomena. Through a detailed literature review, it is understood that many articles were available in the steam and water cycles of power plant. The research work and water conservation studies for auxiliary water systems is not undertaken.

The gap between the water resources and the demand is steadily increasing due to the rapid industrialization and urbanization [17]. At this moment, it is highly imperious to study the aspect of water conservation with strict chemistry control being adhered simultaneously. The modification enforced on the cooling cycles, retrofitting the cooling method, proposing diligent operation and maintenance (O\&M) strategies, technology changes, process control and management strategies reduces the water consumption [18-21]. Preceding and foregoing research focus mainly on the improvement of feed pre-treatment, CT blowdown water reuse or alternative make-up water [22-24]. Assessing the variations in the source water quality is important for any power plant to optimise their cost. This assessment helps to identify the countermeasures to avoid water chemistry problems [25].

The optimization of CT operation with the use of membrane capacitive deionized water reduces water consumption and cost [26]. But, the research work related to minimization of feed and bleed operation concerning the operating and environmental condition is very few. The daily make-up water is added into the system daily, which is calculated as a function of evaporation, blowdown, and drift loss. This make-up water addition can further be reduced by understanding the system behavior and its chemistry requirements. This will minimize plant water consumption. This paper studies the effect of make-up water quality on the system water chemistry and determines the limiting parameter using response surface methodology. Further trend analysis of the system water chemistry was carried to determine the influence of each constituent on the system bleed operation. The main objective is to monitor and analyze the chemistry parameters and their significance in water consumption.

This work is carried out in the following fashion-Collection and analysis of make-up and system water samples, preparation of a correlation matrix between the make-up $\&$ the system water, determining the control parameters, methods of chemistry controls established in the system, 
credible results, and benefits envisaged after incorporating the chemistry control measures in the system.

\section{Materials and methods}

\subsection{Description of the study area}

A typical section of the Raw Water Cooling system with unit coolers is taken for this study. It is a closed-loop cooling water system whose main objective is to remove the reject heat into the atmosphere through evaporative cooling. Due to the raw water loss (drift losses, evaporation losses, and blowdown losses), the freshwater is fed into the system through make-up lines. The cooling water circuit analyzed here contains a Counter Flow Induced Draft Cooling Tower with four cells, two numbers of unit coolers, Chemical dosing system, and raw water pumps. The scheme of the cooling water circuit is presented in Fig. 1.

The raw water requirements for the cooling water circuit is around $2160 \mathrm{~m}^{3} / \mathrm{hr}$ for various plant operations. The capacity of the cooling tower is $540 \mathrm{~m}^{3} / \mathrm{hr}$ per cell. The prevailing atmospheric environmental conditions of the proposed area are given below:

Maximum dry bulb temperature: 43 degree Celsius. Minimum dry bulb temperature: 25 degree Celsius. Design Wet bulb temperature: 28 degree Celsius.

The design data of the cooling tower is given below:

Maximum drift loss: $0.01 \%$ of total CT water.

Design hot water inlet temperature: 39 degree Celsius. Design cold water outlet temperature: 32 degree Celsius.

\subsection{Design provisions for proper chemical control in cooling water system}

1. An on-line self-cleaning filter designed for $10 \%$ of the total cooling water flow rate is provided in the $C T$ basin to clean the suspended solids up to 50 microns.

2. The cooling water system is designed for a cycle of concentration of about 3.0 since the increased level of dissolved salts will promote scale forming property

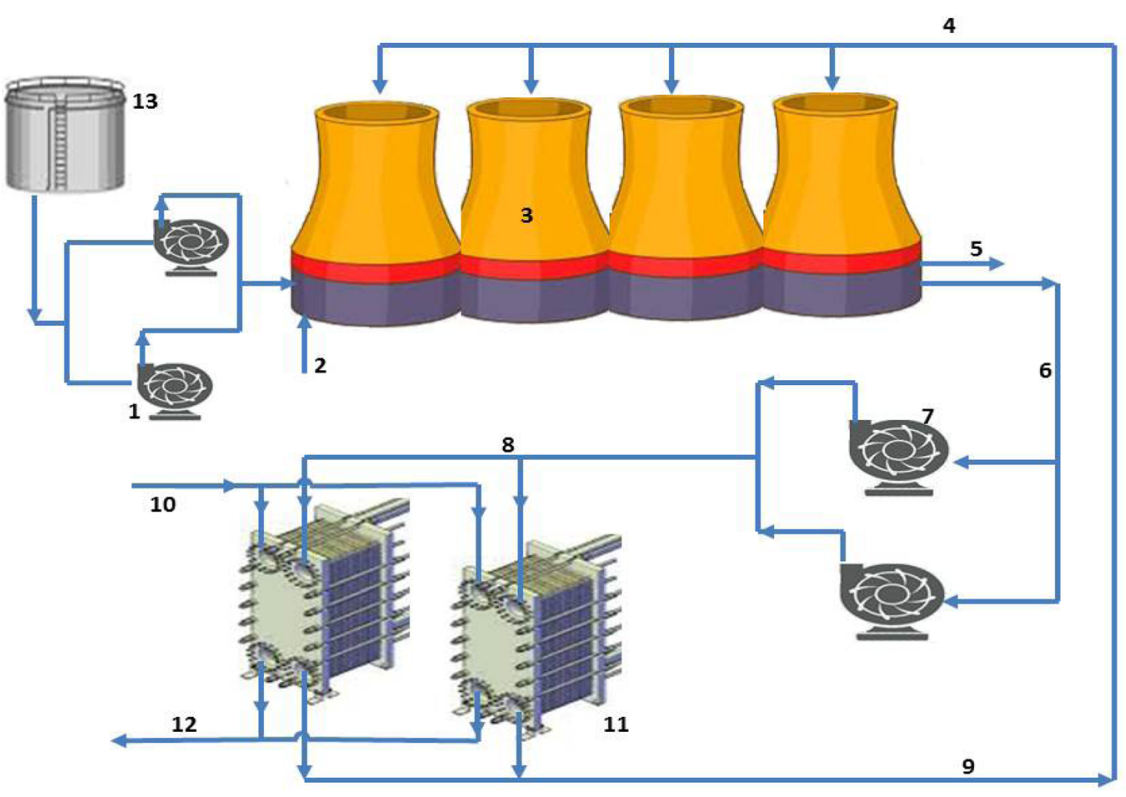

Legend:

1. Sodium Hypochlorite Dosing Pumps

4. Hot Raw water line from Cooler

7. Raw Water Pumps

10. Hot Service Water to Unit Cooler

13. Sodium hypochlorite storage tank
2. Raw Water Makeup

5. Bleed line

8. Raw Water Pump Header line

11. Unit Cooler
3. Cooling Tower

6. Cold Raw Water from CT

9. Hot Raw Water to CT

12. Cold Service Water from Unit cooler

Fig. 1 Cooling water systems for auxiliary systems of nuclear power plant 
of the ions. To avoid scaling, system water should be treated with scale preventing chemicals together with regular desludging (Table 1). Usually, draining of one cell of CT basin is undertaken for desludging activities based on the requirements.

\section{Experimental procedure}

The water samples were collected from Cooling Tower Basin in standard $500 \mathrm{ml}$ Jar using proper sampling procedures. The water quality parameters like $\mathrm{pH}$, Electrical Conductivity, Turbidity, Free Residual Chlorine, cycles of concentration measured with chloride as the base parameter

Table 1 Control parameters for cooling water system

\begin{tabular}{ll}
\hline Description of parameters & Range \\
\hline Cycle of concentration & $\mathrm{COC}<3 ;$ \\
Turbidity & $<2 \mathrm{NTU}$ \\
Residual chlorine & 0.25 to $1 \mathrm{ppm}$ \\
\hline
\end{tabular}

is assessed. All volumetric determination is done as per the standard method for the examination of water and wastewater [27]. The sampling parameters and monitoring the frequency of the system water are provided in Table 2 .

\section{Results and discussion}

\subsection{Analysis of make-up water quality parameters on the system}

The make-up water quality parameter and system water quality observed for three months are analyzed using $t$-test for a range of values lying in the $95 \%$ confidence interval (Table 3). pH, Electrical conductivity, chloride content does not show temporal variation when compared to other parameters like turbidity, hardness, and alkalinity. The variation observed for the individual system water quality parameters is less when compared to that of make-up water quality since only a fraction of system water is being replaced by the make-up water. Hence the

Table 2 Sampling frequency and its significance on the system performance [13]

\begin{tabular}{|c|c|c|c|}
\hline Parameter & $\begin{array}{l}\text { Sampling } \\
\text { frequency }\end{array}$ & Purpose & Effect on the system \\
\hline \multicolumn{4}{|l|}{ Process parameter } \\
\hline Temperature & Daily & To quantify the system performance & $\begin{array}{l}\text { Indicates the efficiency of the heat exchanger. } \\
\text { Identifies the possibilities of cooling failures }\end{array}$ \\
\hline Pressure & Daily & Evaluates the structural integrity & $\begin{array}{l}\text { Indicates the scaling, choking across the heat } \\
\text { exchanger }\end{array}$ \\
\hline Flow rate & Daily & $\begin{array}{l}\text { Indicates the system physical operating } \\
\text { condition }\end{array}$ & $\begin{array}{l}\text { Ensures proper water circulation and water } \\
\text { availability for design heat removal }\end{array}$ \\
\hline \multicolumn{4}{|l|}{ Water chemistry parameter } \\
\hline $\mathrm{pH}$ & Daily & $\begin{array}{l}\text { Indicates the acidic or alkaline state of the } \\
\text { system }\end{array}$ & Corrosion is a function of $\mathrm{pH}$ \\
\hline Electrical conductivity (EC) & Daily & A measure of dissolved ionic species in water & $\begin{array}{l}\text { Metal corrosion and Salt deposition on the } \\
\text { heat exchanger tubes; }\end{array}$ \\
\hline Turbidity & Daily & $\begin{array}{l}\text { To measure the presence of insoluble particu- } \\
\text { lates in the system }\end{array}$ & $\begin{array}{l}\text { Interferes with equipment operation, chocking } \\
\text { of the equipment }\end{array}$ \\
\hline Alkalinity & Weekly & $\begin{array}{l}\text { Represents the ability to neutralize an acid. } \\
\text { Quantifies free hydroxyl, carbonate and } \\
\text { bicarbonate ions }\end{array}$ & React with a hardness to form scale \\
\hline Total hardness & Weekly & Presence of calcium and magnesium ions & Scaling and salt deposition \\
\hline Sodium as $\mathrm{CaCO}_{3}$ & Weekly & Evaluates the build-up of sodium ions & Salt deposition on the system; \\
\hline Silica & Weekly & Ensures proper water chemistry & Silica causes scaling and fouling problems \\
\hline Iron & Weekly & $\begin{array}{l}\text { Quantifies the corrosion products in the } \\
\text { system }\end{array}$ & Indicates the presence of material degradation \\
\hline Chloride & Daily & Ensures proper water chemistry & Most aggressive agent in corrosion \\
\hline Cycles of concentration (COC) & Daily & $\begin{array}{l}\text { Cycles indicate the level of critical water qual- } \\
\text { ity parameter w.r.t to make-up water }\end{array}$ & $\begin{array}{l}\text { An important parameter to determine the feed } \\
\text { rate and cost }\end{array}$ \\
\hline Free residual chlorine (FRC) & Daily & $\begin{array}{l}\text { Measures the water potential to promote bio } \\
\text { growth }\end{array}$ & $\begin{array}{l}\text { Heat exchanger performance deteriorates; } \\
\text { microbial accelerated corrosion occurs }\end{array}$ \\
\hline
\end{tabular}



values in make-up and system water quality parameters
Table 3 Reported range of

\begin{tabular}{|c|c|c|c|c|c|c|c|c|}
\hline \multirow[t]{3}{*}{ Water quality parameter } & \multicolumn{4}{|c|}{ Make-up water } & \multicolumn{4}{|c|}{ System water } \\
\hline & \multicolumn{4}{|c|}{ 95\% Confidence interval } & \multicolumn{4}{|c|}{ 95\% Confidence interval } \\
\hline & Lower & Upper & Mean & S.D & Lower & Upper & Mean & S.D \\
\hline $\mathrm{pH}$ & 6.90 & 7.40 & 7.14 & 0.40 & 8.23 & 8.34 & 8.29 & 0.09 \\
\hline $\mathrm{EC}(\mu \mathrm{S} / \mathrm{cm})$ & 796 & 879 & 837 & 65 & 2489 & 3191 & 2840 & 552 \\
\hline Turbidity, NTU & 1.60 & 4.90 & 3.25 & 2.60 & 1.23 & 2.77 & 2.00 & 1.20 \\
\hline M-alk, ppm & 22 & 45 & 33 & 18 & 95 & 145 & 120 & 39 \\
\hline $\mathrm{CH}, \mathrm{ppm}$ & 14.90 & 39.80 & 27.30 & 19.58 & 54.23 & 68.27 & 61.25 & 11.05 \\
\hline $\mathrm{MH}, \mathrm{ppm}$ & 10.40 & 21.40 & 15.90 & 8.62 & 25.94 & 49.89 & 37.92 & 18.85 \\
\hline $\mathrm{Na}, \mathrm{ppm}$ & 129.90 & 227.60 & 178.80 & 76.80 & 425.86 & 880.31 & 653.08 & 357.62 \\
\hline Silica, ppm & 1.80 & 2.80 & 2.30 & 0.79 & 7.63 & 11.20 & 9.42 & 2.80 \\
\hline Iron, $\mathrm{ppb}$ & 54.40 & 143.1 & 98.75 & 69.80 & 53.36 & 125.31 & 89.30 & 56.62 \\
\hline Chloride, ppm & 271 & 337 & 304 & 51 & 807 & 1171 & 989 & 286 \\
\hline
\end{tabular}
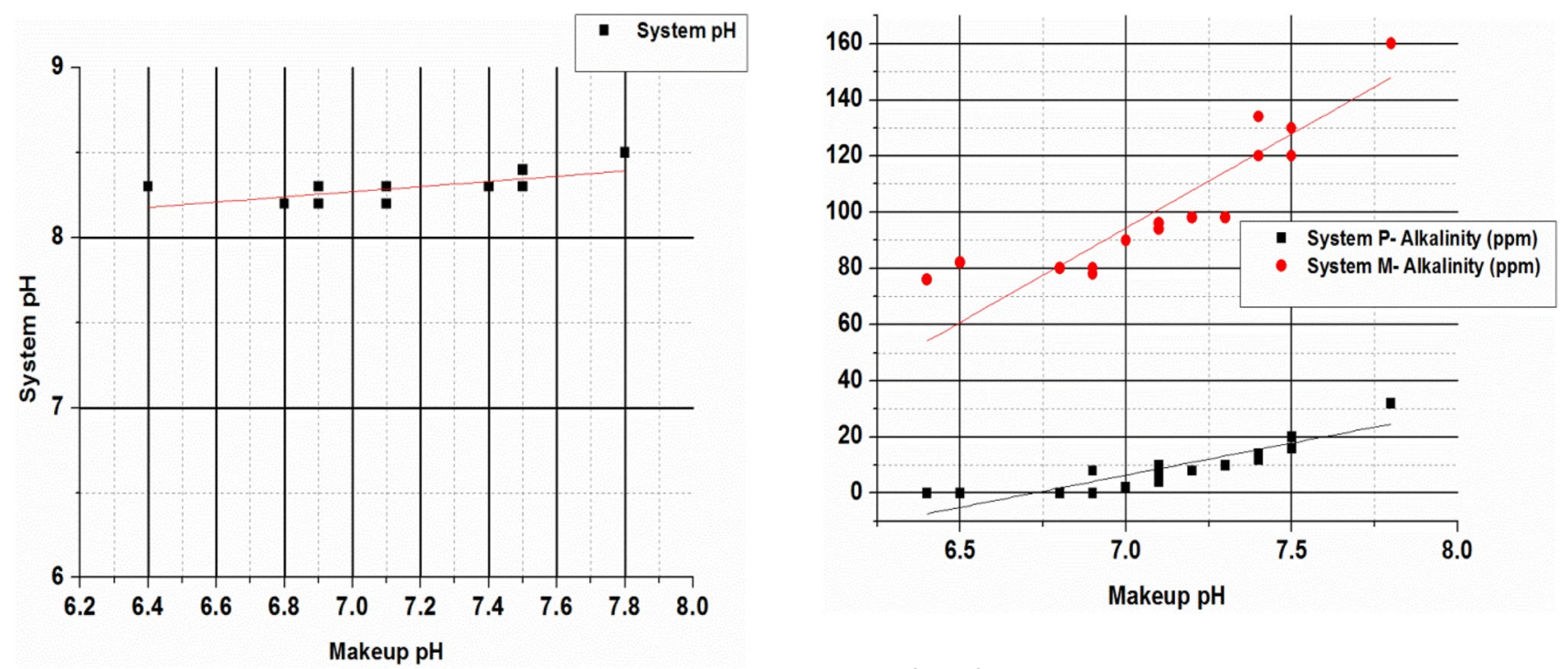

Fig. 3 Effect of make-up pH on system alkalinity

Fig. 2 Effect of make-up pH on system pH and system LSI

time-based variation is prominent in make-up water rather than system water.

\subsection{Make-up pH, alkalinity, conductivity}

The make-up water $\mathrm{pH}$ was found to be in the range of 6.4 to 7.8 . The system $\mathrm{pH}$ does not show significant variation to this operating range (Fig. 2). The effect of make-up water $\mathrm{pH}$ on system M-alkalinity (Methyl Orange alkalinity) and P-alkalinity (Phenolphthalein alkalinity) was seen when the $\mathrm{pH}$ is above 7. A slight increase in the $\mathrm{OH}^{-}$ions were seen in the system when $\mathrm{pH}$ is above 7. At $\mathrm{pH}$ above 7 , the M-alkalinity is found to increase by an amount equal to $\mathrm{P}$-alkalinity. This states that there is an increase in $\mathrm{OH}^{-}$ions as make-up water $\mathrm{pH}$ goes beyond 7 . The carbonate and bicarbonate ions do not increase when compared to the hydroxyl ions (Fig. 3).

The make-up conductivity tested were found to be in the range of $700-1000 \mu \mathrm{S} / \mathrm{cm}$. Figure 4 states that a definite relation cannot be arrived between the EC and system sodium \& chloride levels due to clustering values. A correlation value of Makeup EC and System Sodium \& chloride levels from Table 4 is also not significant. It was deduced that the system limits could not be maintained if the make-up conductivity goes above $950 \mu \mathrm{S} / \mathrm{cm}$ (Fig. 4). Other system parameters were not altered much. From the make-up water analysis, it can be stated that the make-up electrical conductivity does not exceed the critical values with $95 \%$ confidence (Table 3 ).

The make-up water M-alkalinity and P-alkalinity was not influencing the system water chemistry parameters as their levels are very less in the source water itself. Similarly, 


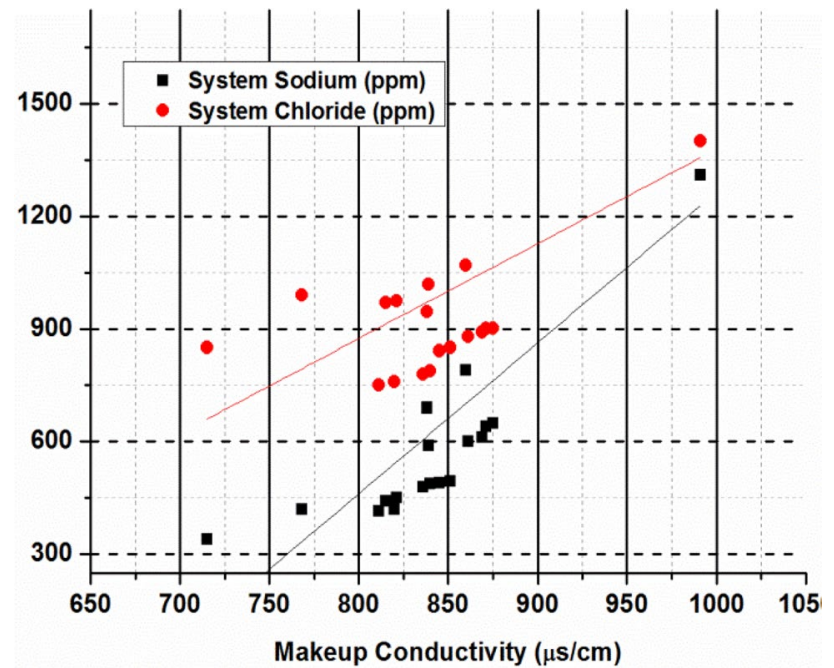

Fig. 4 Effect of make-up conductivity on system sodium and chloride ions

there is no prominent influence of make-up water calcium and magnesium hardness in the system.

\subsection{Make-up RSI, LSI}

The make-up RSI was found to be in the range of 9 to 13.1 . It was found that the alkaline environment is prevalent in the system due to the addition of sodium hypochlorite as a biocide. There is a strong dominance of the formation of sodium hydroxide in the system, which reduces the RSI in the system. It is understood that the system RSI of 8 and below is seen to be neutral, and no unruly results were seen in the system (Fig. 5).

The make-up LSI was seen to be in the range of 0.8 to 3.35. As make-up LSI was increased, there is a directional tendency of the system to go from corrosive to scaling conditions. The system LSI did not go beyond +0.5 and -0.5 during this test period. Even though the make-up $\mathrm{RSI}$ and LSI values were high, the system RSI and LSI levels were found to be within limits.

\subsection{Correlation between system water and make-up water quality}

The Pearson's correlation coefficient determines the degree of a linear relationship between any two variables on a scale of -1 (perfect inverse relation) through 0 (no relation) to +1 (perfect sympathetic relation) [28]. The Pearson correlation matrix (Table 4) is utilized to study the effect of individual make-up water parameters on the system water chemistry condition. The water quality parameters whose correlation value has a significance level of 0.01 is discussed in the subsequent lines.
It was observed that make-up $\mathrm{pH}$ is influencing the formation of system chloride ions, system electrical conductivity linearly [29]. A negative correlation exists between the make-up water Ryznar Stability Index (RSI) and electrical conductivity. The system chloride and sodium concentration are influenced by the make-up sodium and chloride content. The make-up iron content establishes a negative relation with system RSI, LSI. The turbidity of the water is not governed by the make-up $\mathrm{pH}$ or conductivity. Turbidity levels increase due to the presence of suspended solids, organic matter, or any other inorganic substances. System Operation data is studied to analyze the levels of turbidity. It was found that lower levels of biocide and improper flushing of the system lines increase the turbidity. To maintain the turbidity levels, it is necessary to maintain the free residual chlorine levels within 0.25 to $1 \mathrm{ppm}$. The other make-up water parameters like P-alkalinity, Magnesium Hardness, silica content does not affect the system water quality parameter to a significant level since their concentration is minimal in make-up water. There is no prominent influence of make-up water electrical conductivity on the system individual water quality parameter. From this correlation, we can state that make-up water qualities like sodium, chloride, RSI, LSI has a noticeable influence on the system. The above study indicates that the critical parameter to be observed is chloride and sodium concentration. In most of the systems, hardness, silica, and conductivity play a significant role. This study highlights the importance of studying, analyzing, and decision making in individual systems rather than applying existing guidelines.

\subsection{Optimization of critical parameters:}

Response surface methodology is utilized in a wide spectrum of research activities to design and optimize the experimental runs [30-33]. This method is adopted to determine the critical values of make-up chloride and sodium content to prevent chemistry violations in the system. These critical parameters are optimized using design expert for the reported range of values obtained for the make-up water using central composite design [34-37]. The limiting values identified for the above make-up water to maintain amicable system water chemistry condition is given as follows:

Makeup chloride content: $295 \mathrm{mg} / \mathrm{l}$ as $\mathrm{CaCO}_{3}$. Make-up sodium content: $116 \mathrm{mg} / \mathrm{l}$ as $\mathrm{CaCO}_{3}$. System chloride content: $850 \mathrm{mg} / \mathrm{l}$.

System sodium content: 500 mg/l.

Figures 6 and 7 shows the response surface graphs for sodium and chloride levels in the system. The interrelation between the make-up sodium and system sodium 


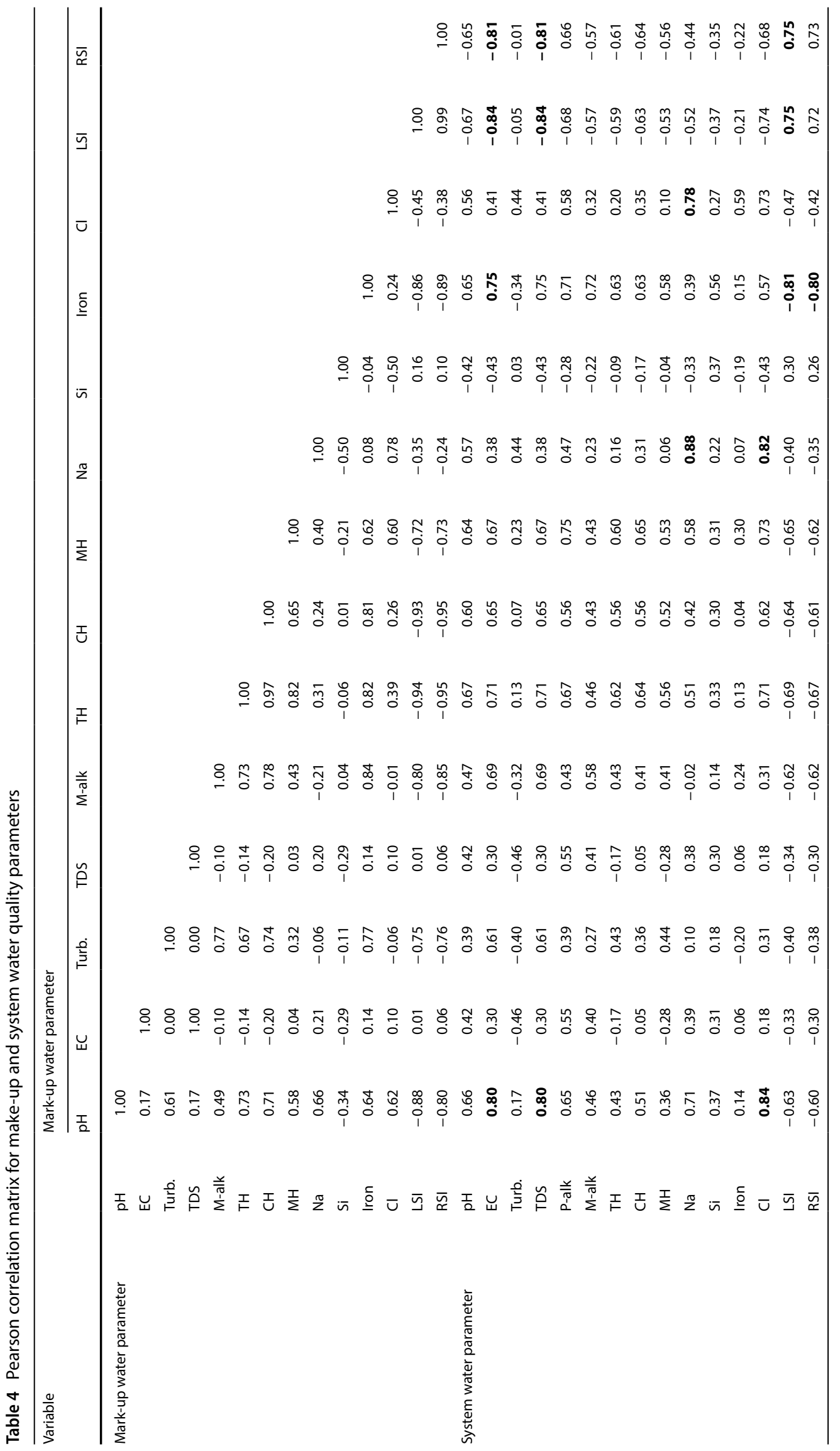




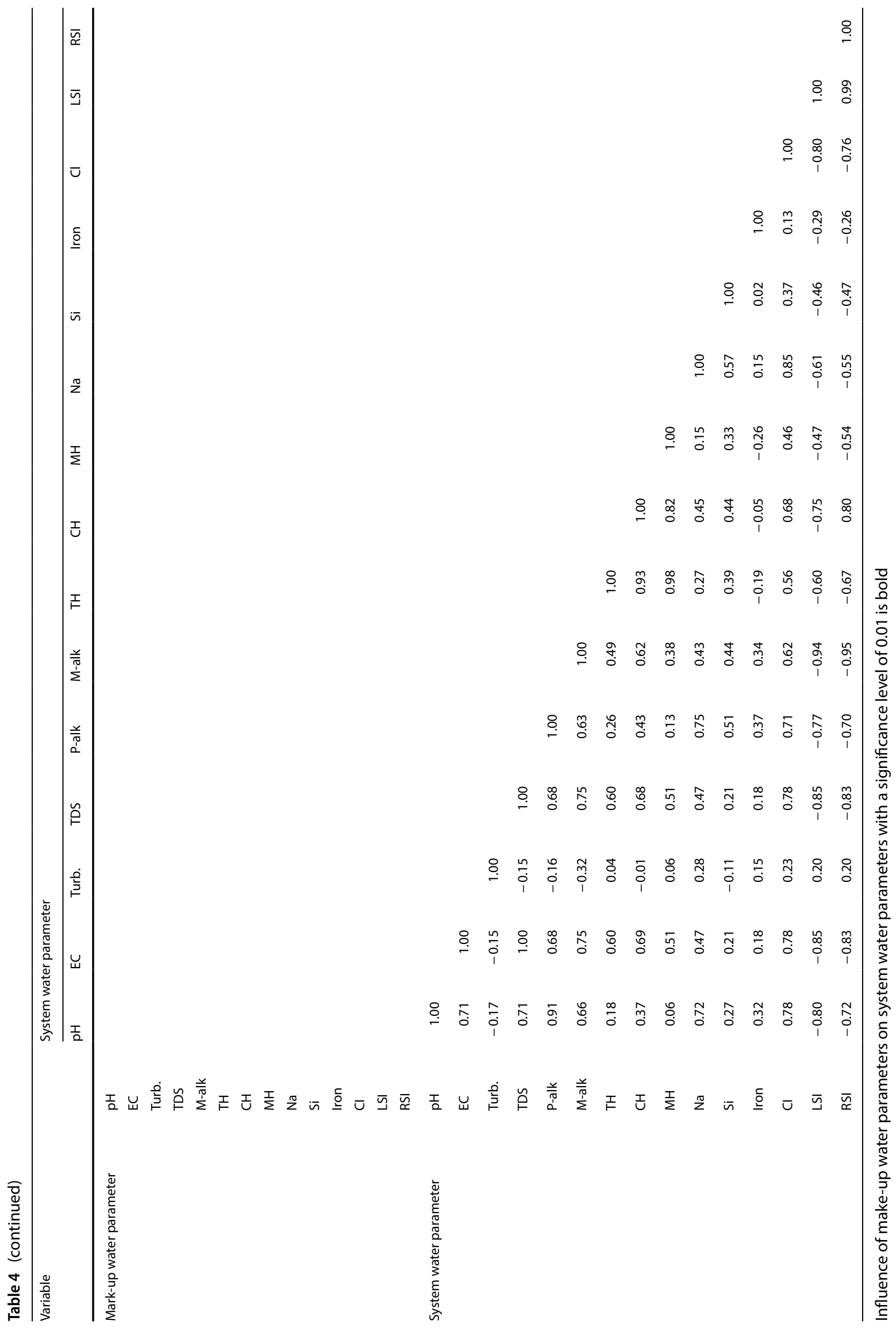




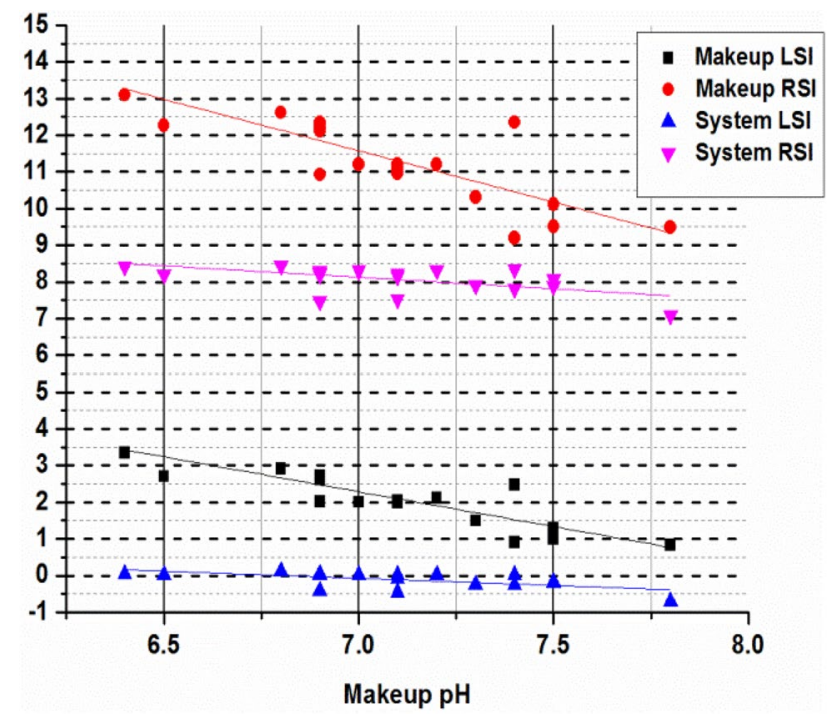

Fig. 5 Effect of make-up pH on make-up LSI, RSI and system LSI, RSI

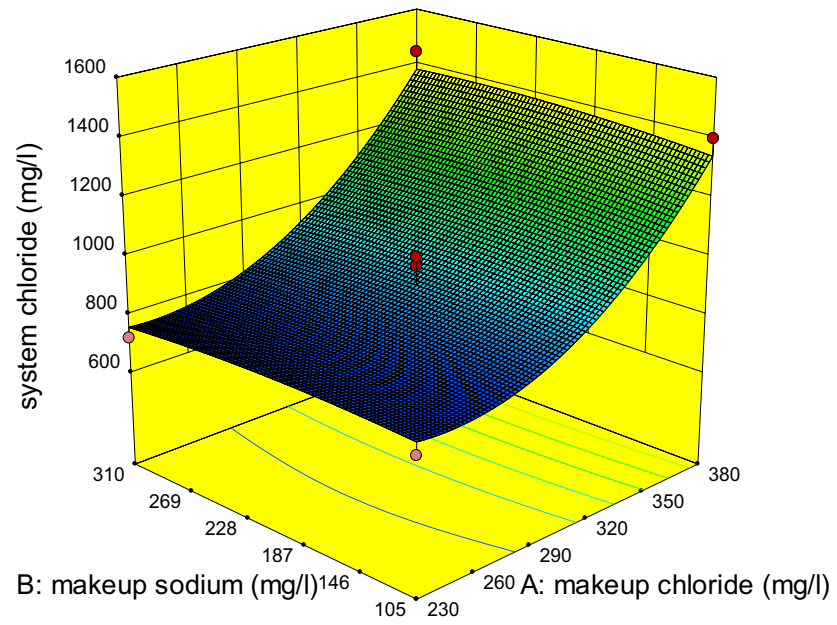

Fig. 6 Response surface graphs for system chloride

is predominant. Make-up sodium does not have a significant change in the system chloride. The same trend is observed in the system chloride levels. The residuals are regularly distributed along the straight line for both the response variable. Only a little deviation is reported in Figs. 8 and 9. Therefore, the model could be used for dependent variable prediction. The analysis of variance is presented in Tables 5 and 6, which evaluates the significance of the model. $R^{2}$ value of the regression model for both the parameters is close to 1 , which indicates that there is a small difference between the predicted and measured value. The $p$-value is less than 0.0001 for system sodium and 0.0002 for system chloride levels. It is understood that the system is having a good fit.

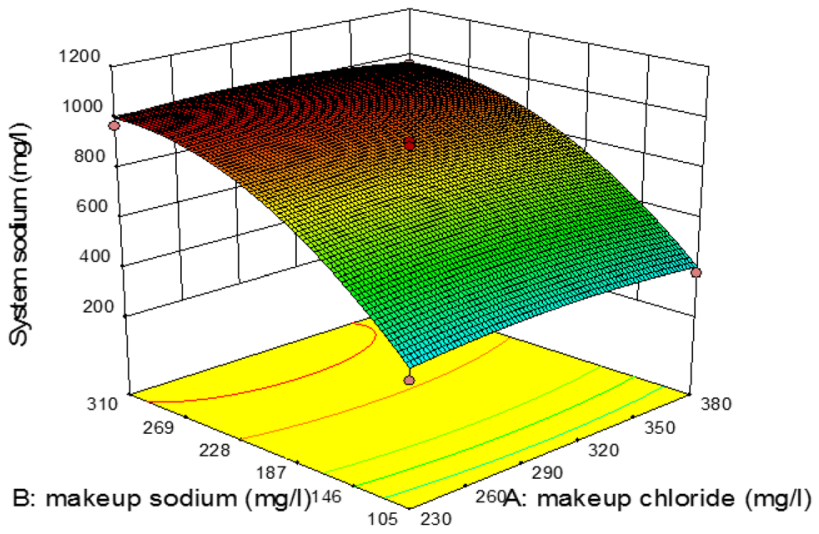

Fig. 7 Response surface graphs for system sodium

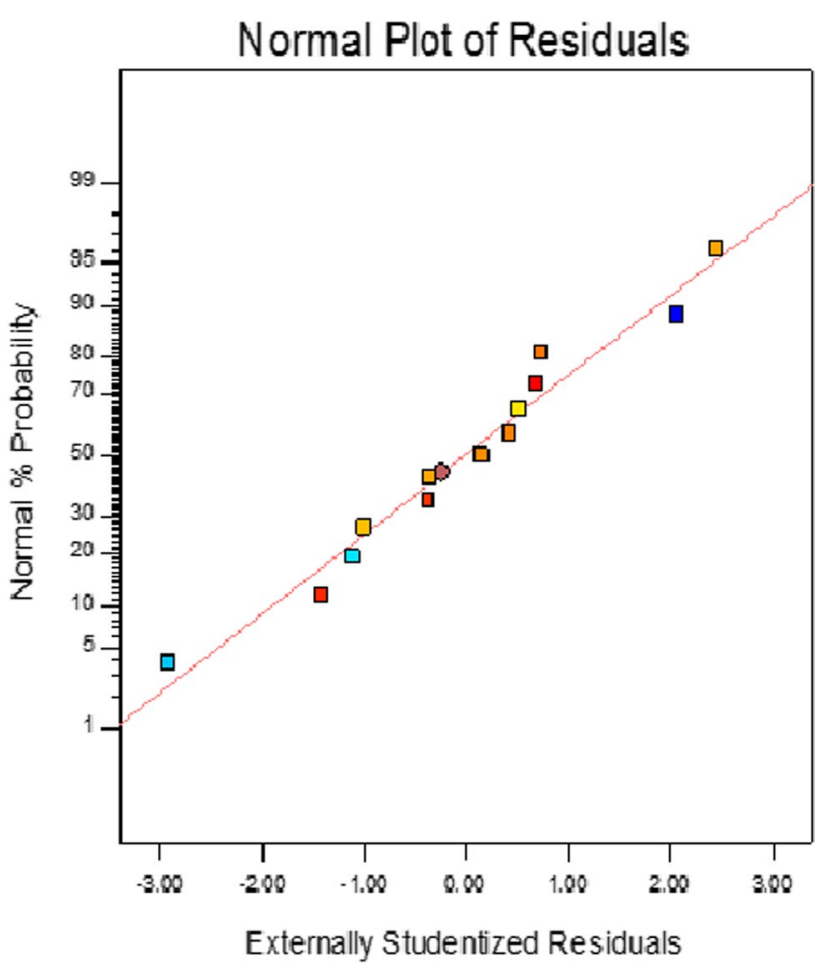

Fig. 8 Normal probability plot of the residuals for system sodium

To summarise the work, the relation between the makeup water and system water chemistry is analyzed and assessed. It is found that the make-up water parameter chloride and sodium have got a definite positive relation with system sodium and chloride content. The methods to optimize the water chemistry limits and in turn, save water were studied, and the following is recommended from the study.

- Limit the make-up water sodium and chloride levels to 110 and $290 \mathrm{mg} / \mathrm{l}$. 


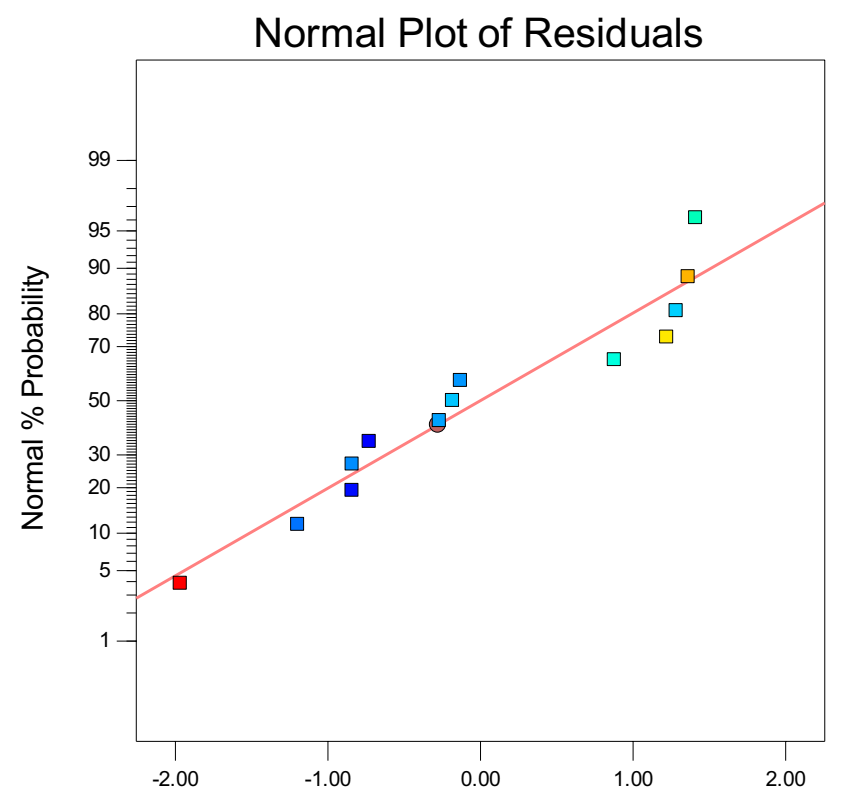

Externally Studentized Residuals

Fig. 9 Normal probability plot of the residuals for system chloride

Case 1: Make-up water sodium and chloride levels more than the limiting parameter for a maximum of 5 days.

Generally, the Nuclear power plant employs a separate Demineralized Plant to produce demineralized water (DM water) for its steam-water system. The option of mixing the make-up water with demineralized water for a maximum of five days is seen a viable option if the limiting criteria is not met in any of the days. The DM plant for a nuclear power plant is designed with $100 \%$ redundancy. Hence it will cater to the make-up water requirement at site. The production cost of DM water is justifiable only when it is used for a maximum of five days. The detailed aspect of mixing DM water and make-up water is yet another area of research.

Case 2: Make-up water sodium and chloride levels more than the limiting parameter continuously for six days or more in a week.

With $95 \%$ confidence, it is seen that make-up water chemistry levels do not violate continuously for more than five days. If any of the reported violations repeatedly occur for more than five days, it is recommended to design, install an appropriate raw water treatment system.

With the above limiting values on sodium and chloride, it is possible to reduce blowdowns by 1 number per 25 days. The requirements of code to limit chloride are $250 \mathrm{ppm}$ [38]. However, in the absence of a good source, it is permitted to use till $1000 \mathrm{ppm}$. The levels of sodium and chloride in make-up water can be checked every day. If higher levels of make-up sodium and chloride are seen in any of the day, system process parameters are studied to forego the usage of make-up water for that particular day. The decision to abstain or limit the feed operation can be established with the above sodium and chloride levels. This aspect of developing and assessing a warning system based on the risk associated with the seasonal and temporal deterioration of raw water quality can be undertaken by probability estimation methods [39-41]. Further water reduction aspects were studied by investigating the system water chemistry parameters and bleed operation.

\subsection{Analysis of the system water chemistry conditions}

Typical Weekly review of the system sample was undertaken to study the effect of Electrical Conductivity, Chloride ions, and TDS on Cycles of Concentration (Table 7). It was seen that Chlorides were found to increase the cycles of concentration on the majority.

Table 5 ANOVA table for the parameter system chloride

\begin{tabular}{llllrr}
\hline Source & Df & $\begin{array}{l}\text { Sum of } \\
\text { squares }\end{array}$ & Mean square & $F$ value & $p$-value Prob $>F$ \\
\hline Model-system chloride & $9.458 \mathrm{E}+005$ & 5 & $1.892 \mathrm{E}+005$ & 28.78 & 0.0002 \\
A-makeup chloride & $7.110 \mathrm{E}+005$ & 1 & $7.110 \mathrm{E}+005$ & 108.19 & $<0.0001$ \\
B-makeup sodium & 301.87 & 1 & 301.87 & 0.046 & 0.8364 \\
AB & 756.25 & 1 & 756.25 & 0.12 & 0.7444 \\
A $^{2}$ & $2.209 \mathrm{E}+005$ & 1 & $2.209 \mathrm{E}+005$ & 33.62 & 0.0007 \\
$\mathrm{~B}^{2}$ & 2587.88 & 1 & 2587.88 & 0.39 & 0.5502 \\
Residual & $46,002.55$ & 7 & 6571.79 & & 0.4262 \\
Lack of fit & $21,465.75$ & 3 & 7155.25 & 1.17 & Not significant \\
Pure error & $24,536.80$ & 4 & 6134.20 & & \\
$R^{2}=0.95 ; R^{2}{ }_{\text {adj }}=0.92 ; \mathrm{CV}(\%)=8.09$ & & & & \\
Equation : System $\mathrm{Cl} .=904.2+298.12 * A+6.14 * B+13.75 * A B+178.21 * A^{2}-19.29 * B^{2}$ & \\
\hline
\end{tabular}


Table 6 ANOVA table for the parameter system sodium

\begin{tabular}{llllrll}
\hline Source & Sum of squares & df & Mean square & $F$ Value & $p$-value Prob $>F$ & \\
\hline Model-system sodium & $8.488 \mathrm{E}+005$ & 5 & $1.698 \mathrm{E}+005$ & 117.20 & $<0.0001$ & Significant \\
A-makeup chloride & 374.16 & 1 & 374.16 & 0.26 & 0.6269 & \\
B-makeup sodium & $6.771 \mathrm{E}+005$ & 1 & $6.771 \mathrm{E}+005$ & 467.45 & $<0.0001$ & \\
$\mathrm{AB}$ & 324.00 & 1 & 324.00 & 0.22 & 0.6506 & \\
$\mathrm{~A}^{2}$ & 7912.18 & 1 & 7912.18 & 5.46 & 0.0521 & \\
$\mathrm{~B}^{2}$ & $1.698 \mathrm{E}+005$ & 1 & $1.698 \mathrm{E}+005$ & 117.22 & $<0.0001$ & \\
Residual & $10,139.26$ & 7 & 1448.47 & & & Not significant \\
Lack of fit & 7846.46 & 3 & 2615.49 & 4.56 & 0.0883 & \\
Pure error & 2292.80 & 4 & 573.20 & & & \\
$R^{2}=0.99 ; R^{2}$ adj $=0.98 ; \mathrm{CV}(\%)=4.96$ & & & & & \\
Equation : System Na. $=884.2+6.84 * A+290.92 * B+9 * A B+33.73 * A^{2}-156.23 * B^{2}$ \\
\hline
\end{tabular}

Table 7 Weekly variation of cycles of concentration with different parameters

\begin{tabular}{llll}
\hline Week & $\begin{array}{l}\text { COC based on } \\
\text { conductivity }\end{array}$ & $\begin{array}{l}\text { COC based on } \\
\text { TDS }\end{array}$ & $\begin{array}{l}\text { COC based } \\
\text { on chloride }\end{array}$ \\
\hline Week 1 & 3.0 & 3.0 & 3.3 \\
Week 2 & 2.9 & 2.9 & 3.1 \\
Week 3 & 3.0 & 3.0 & 3.2 \\
Week 4 & 2.7 & 2.7 & 3.1 \\
Week 5 & 2.6 & 2.6 & 3.0 \\
Week 6 & 3.0 & 3.0 & 3.0 \\
Week 7 & 2.9 & 2.9 & 3.1 \\
Week 8 & 3.5 & 3.5 & 3 \\
Week 9 & 2.9 & 2.9 & 3.2 \\
Week 10 & 3.1 & 3.1 & 3 \\
\hline
\end{tabular}

The main contributing factor to blowdown is Cycles of concentration due to chloride concentration. Other parameters were found to be in the range most of the time. Of the total samples tested for cycles, nearly $40 \%$ of the samples were slightly above the normal range (Fig. 10). COC was found to be within limits after adhering to the make-up water quality limiting criteria and adopting strict chemical conditioning.

One hour of system bleed requires nearly $50 \mathrm{~m}^{3}$ of water. The total blowdown water for the period was 8815 $\mathrm{m}^{3}$. With proper Chemistry conditioning, unnecessary blowdowns of $500 \mathrm{~m}^{3}$ water due to turbidity level violation and $360 \mathrm{~m}^{3}$ water due to limiting criteria could have been avoided (Fig. 11). Hence, nearly $10 \%$ of the water has been saved by practicing limiting criteria, proper monitoring, and chemistry conditioning in the plant. The overall study indicated that with appropriate chemical conditioning and minimal blowdowns, it is possible to maintain system healthiness and also save water.

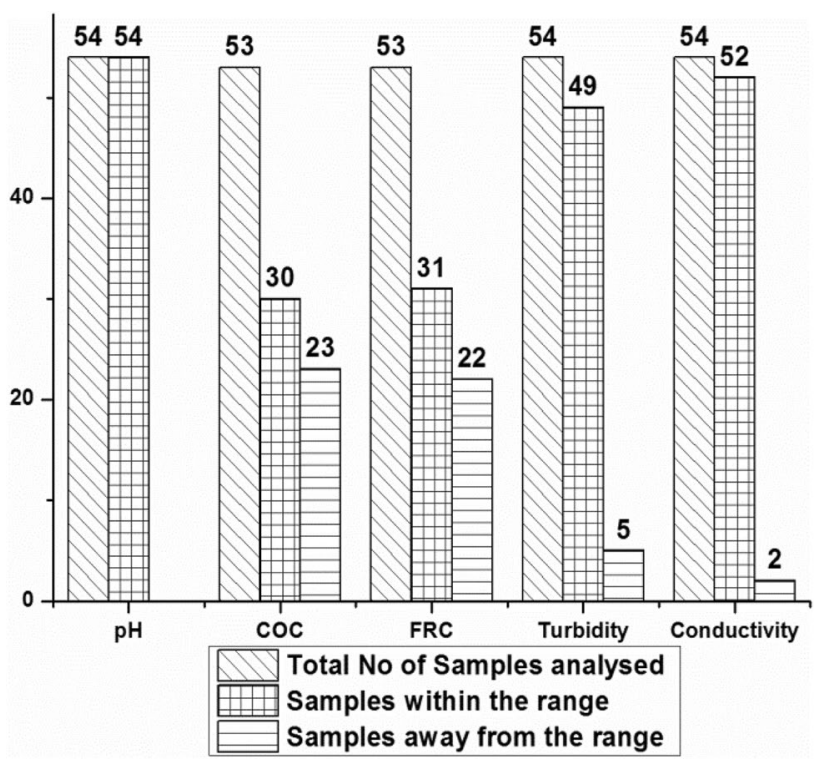

Fig. 10 Reportable deviation of water chemistry parameters

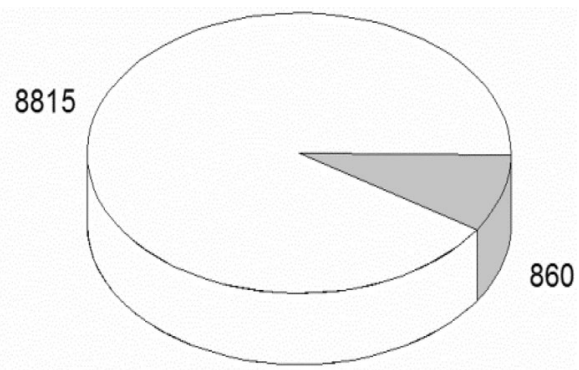

Total Feed and Bleed water $\left(\mathrm{m}^{3}\right)$ Water saved $\left(\mathrm{m}^{3}\right)$

Fig. 11 Water Savings with precise Chemistry Control 


\section{Conclusion}

The following are the conclusions arrived from this work.

- The determining factor for the cooling water system bleed operation is found to be the cycles of concentration with chloride content.

- A definite correlation exists between the makeup water qualities like $\mathrm{pH}$, sodium, chloride on the system water quality parameters- EC, chloride, and sodium ions.

- By limiting the critical values of make-up sodium to $116 \mathrm{mg} / \mathrm{l}\left(\mathrm{CaCO}_{3}\right)$ and chloride to $295 \mathrm{mg} / \mathrm{l}\left(\mathrm{CaCO}_{3}\right)$ along with strict chemistry conditioning, it is possible to save nearly $10 \%$ of the water.

From this study, It can be stated that proper monitoring and chemical conditioning helps to conserve not only water but also the operation \& maintenance cost of the system equipment. The cost of repairing the leakages, leak ingress of radioactive water due to poor chemistry control in the nuclear power plant is considered severe. Hence, the chemistry-related damages and failures were given due importance to prevent outages in the field of research. The above limiting criteria provide some insight into preventing chemistry-related failures. The studies on the aspect of simulating and testing the specific industrial condition rather than common industrial conditions need attention. This study can further be extended to field-specific optimization of free residual chlorine levels for controlling turbidity levels in the system.

Author contributions Conceptualisation and Original draft preparation by PS. Data collection and analysis by JN. Resources provided by GVRRSGSP. Review and Supervision by GS, BA. Comments on previous versions of manuscript by all authors.

\section{Compliance with ethical standards}

Conflict of interest On behalf of all authors, the corresponding author states that there is no conflict of interest.

\section{References}

1. Atomic Energy Regulatory Board (2003) Safety Classification and seismic catergorisation for structures, systems and components of pressurized heavy water reactors safety guide no. AERB/NPP-PHWR/SG/D-1

2. Nyman R, Erixon S, Tomic B, Lydell B (1996) Reliability of piping system components vol 4 . The pipe failure event database. Swedish Nuclear Power Inspectorate. https://inis.iaea.org/
collection/NCLCollectionStore/_Public/28/018/28018605. pdf. Accessed 25 Aug 2019

3. Tabesh M, Soltani J, Farmani SDA (2009) Assessing pipe failure rate and mechanical reliability of water distribution networks using data driven modelling. J Hydroinf 11:1-17. https://doi. org/10.2166/hydro.2009.008

4. International Atomic Energy Agency (1997) Generic component reliability data for research reactor PSA TECDOC-930. https:// www.iaea.org/publications/5582/generic-component-reliabilit y-data-for-research-reactor-psa. Accessed 20 May 2020

5. Rajakovic-Ognjanovic VN, Zivojinovic DZ, Grgur BN, Rajakovi LV (2011) Improvement of chemical control in the water-steam cycle of thermal power plants. Appl Therm Eng 31:119-128. https://doi.org/10.1016/j.applthermaleng.2010.08.028

6. Pourali O, Kadijani HG, Khangheshlaghi FM (2017) Chemical conditioning and monitoring to control and minimize chemistryrelated damages in Heller dry cooled combined cycle power plants. Anti-Corros Methods Mater 64(2):188-208. https://doi. org/10.1108/ACMM-02-2016-1648

7. Uchida S, Katsumura Y (2013) Water chemistry technologyone of the key technologies for safe and reliable nuclear power plant operation. J Nucl Sci Technol 50(4):346-362. https://doi. org/10.1080/00223131.2013.773171

8. Lister D, Uchida S (2015) Determining water chemistry conditions in nuclear reactor coolants. J Nucl Sci Technol 52(4):451466. https://doi.org/10.1080/00223131.2014.973460

9. Kawamura H, Shoda Y, Terachi T, Katsumura Y, Uchida S, Mizuno T, Muroya Y, Tsuzuki Y, Umehara R, Hirano H, Nishimura T (2019) PWR secondary water chemistry guidelines in Japan-purpose and technical background. Prog Nucl Energy 114:121-137. https ://doi.org/10.1016/j.pnucene.2019.01.027

10. Rodriguez MA (2020) Corrosion control of nuclear steam generators under normal operation and plant-outage conditions: a review. Corros Rev 38(3):195-230. https://doi.org/10.1515/corrr ev-2020-0015

11. Bhatt MS (2006) Effect of water side deposits on the energy performance of coal fired thermal power plants. Energy Convers Manag 47(9):1247-1263. https://doi.org/10.1016/j.encon man.2005.07.002

12. Lee J-M, Jeon S-H, Kim K-S, Han J, Hur DH (2020) Effects of pH control agents on magnetite deposition on steam generator tubes. Ann Nucl Energy 143:107486. https://doi.org/10.1016/j. anucene.2020.107486

13. International Atomic Energy Agency (2011) Good practices for water quality management in research reactors and spent fuel storage facilities Nuclear energy series No. NP-T-5.2

14. Hoang TA, Ming Ang $H$, Rohl AL (2007) Effect of temperature on scaling of calcium sulphate in pipes. Powder Technol 179:31-37. https://doi.org/10.1016/j.powtec.2006.11.013

15. Quddus A, Al-Hadhrami LM (2009) Hydrodynamically deposited $\mathrm{CaCO}_{3}$ and $\mathrm{CaSO}_{4}$ scales. Desalination 246:526-533. https://doi. org/10.1016/j.desal.2008.11.005

16. Larin BM, Larin AB, Bushuev EN (2019) Determination of salt component concentrations in boiler water using conductivity and pH measurements. Therm Eng 66:593-598. https://doi. org/10.1134/S0040601519080056

17. Shafiei M, Moosavirad SH, Azimifard A, Biglari S (2020) Water consumption assessment in Asian chemical industries supply chains based on input-output analysis and one-way analysis of variance. Environ Sci Pollut Res 27:12242-12255. https://doi. org/10.1007/s11356-020-07707-6

18. Pan S-Y, Snyder SW, Packman Al, Lin YJ, Chiang P-C (2018) Cooling water use in thermoelectric power generation and its associated challenges for addressing water-energy nexus. Water-Energy Nexus 1:26-41. https://doi.org/10.1016/j. wen.2018.04.002 
19. Sanders KT, Blackhurst MF, King CW, Webber ME (2014) The Impact of water use fees on dispatching and water requirements for water-cooled power plants in Texas. Environ Sci Technol 48:7128-7134. https://doi.org/10.1021/es500469q

20. Alkaya E, Demirer GN (2015) Reducing water and energy consumption in chemical industry by sustainable production approach: a pilot study for polyethylene terephthalate production. J Clean Prod 99:119-128. https://doi.org/10.1016/j.jclep ro.2015.02.087

21. Chen L, Ding X, Xiongying Wu (2015) Water management tool of industrial products: a case study of screen printing fabric and digital printing fabric. Ecol Ind 58:86-94. https://doi. org/10.1016/j.ecolind.2015.05.045

22. Farahani MHDA, Borghei SM, Vatanpour V (2016) Recovery of cooling tower blowdown water for reuse: the investigation of different types of pretreatment prior nanofiltration and reverse osmosis. J Water Process Eng 10:188-199. https://doi. org/10.1016/j.jwpe.2016.01.011

23. Frick JM, Féris LA, Tessaro IC (2014) Evaluation of pretreatments for a blowdown stream to feed a filtration system with discarded reverse osmosis membranes. Desalination 341:126-134. https ://doi.org/10.1016/j.desal.2014.02.033

24. Koeman-Stein NE, Creusen RJM, Zijlstra M, Groot CK, Van den Broek WBP (2016) Membrane distillation of industrial cooling tower blowdown water. Water Res Ind 14:11-17. https://doi. org/10.1016/j.wri.2016.03.002

25. Toller S, Giambastiani BMS, Greggio N, Antonellini M, Vasumini I, Dinelli E (2020) Assessment of Seasonal changes in water chemistry of the Ridracoli Water Reservoir (Italy): implications for water management. Water 12(2):581-592. https://doi. org/10.3390/w12020581

26. De Schepper W, Vanschepdael C, Huynh H, Helsen J (2020) Membrane capacitive deionization for cooling water intake reduction in thermal power plants: lab to pilot scale evaluation. Energies 13(6):1305. https://doi.org/10.3390/en13061305

27. AWWA (1998) Standard methods for examination of water and wastewater

28. Chandrasekaran S, Sankaran Pillai G, Venkatraman B (2020) Spatial and heavy metal assessment in beach sands of east coast of Tamil Nadu, India. Environ Nanotechnol Monit Manag 14:100324. https://doi.org/10.1016/j.enmm.2020.100324

29. McCleskey R, Blaine DK, Nordstrom JN, Ryan JW, Ball, (2012) A new method of calculating electrical conductivity with applications to natural waters. Geochim Cosmochim Acta 77:369-382. https://doi.org/10.1016/j.gca.2011.10.031

30. Varank G, Guvenc SY, Gurbuz G, Engin GO (2016) Statistical optimization of process parameters for tannery wastewater treatment by electrocoagulation and electro-Fenton techniques. Desalin Water Treat 57(53):25460-25473. https://doi. org/10.1080/19443994.2016.1157042

31. Canals O, Serrano-Suárez A, Salvadó H, Méndez J, Cervero-Aragó S, Ruiz V, de Porras J, Dellundé RA (2015) Effect of chlorine and temperature on free-living protozoa in operational man-made water systems (cooling towers and hot sanitary water systems) in Catalonia. Environ Sci Pollut Res 22(9):6610-6618. https://doi. org/10.1007/s11356-014-3839-y

32. Lúcia V, dos Santos A, Veiga A, Mendonça RS, Alves AL, Pagnin S, Santiago VMJ (2015) Reuse of refinery's tertiary-treated wastewater in cooling towers: microbiological monitoring. Environ Sci Pollut Res 22(4):2945-2955. https://doi.org/10.1007/s1135 6-014-3555-7

33. Sathiya Prabhakaran SP, Swaminathan G, Joshi VV (2020) Energy conservation - a novel approach of co-combustion of paint sludge and Australian lignite by principal component analysis, response surface methodology and artificial neural network modelling. Environ Technol Innov. 20:101061. https://doi. org/10.1016/j.eti.2020.101061

34. Garg MC, Joshi H (2017) Comparative assessment and multivariate optimization of commercially available small scale reverse osmosis membranes. J Environ Inf 29(1):39-52. https://doi. org/10.3808/jei.201700357

35. Guesmi F, Louati I, Hannachi C, Hamrouni B (2020) Optimization of boron removal from water by electrodialysis using response surface methodology. Water Sci Technol 81(2):293-300. https:// doi.org/10.2166/wst.2020.105

36. Zbair M, Ainassaari K, El Assal Z, Ojala S, El Ouahedy N, Keiski RL, Bensitel M, Brahmi R (2018) Steam activation of waste biomass: highly microporous carbon, optimization of bisphenol A, and diuron adsorption by response surface methodology. Environ Sci Pollut Res 25(35):35657-35671. https://doi.org/10.1007/ s11356-018-3455-3

37. Montgomery Douglas C (2013) Design and analysis of experiments, 8th edn. Wiley, Hoboken

38. Bureau of Indian Standards (1999) Treatment of water for cooling towers-code of practice, Indian Standard: 8188

39. Rak J, Pietrucha-Urbanik K (2019) An approach to determine risk indices for drinking water-study investigation. Sustainability 11:3189-3201. https://doi.org/10.3390/su11113189

40. Rak J, Tchórzewska-Cieslak B, Pietrucha-Urbanik K (2019) A hazard assessment method for waterworks systems operating in self-government units. Int J EnvironRes Public Health 16:767779. https://doi.org/10.3390/ijerph16050767

41. Khan AS, Hakim A, Waliullah MR, Mandal BH, Abdullah-AlMamun FA (2019) Seasonal water quality monitoring of the Bhairab River at Noapara industrial area in Bangladesh. SN Appl Sci 1:586. https://doi.org/10.1007/s42452-019-0583-4

Publisher's Note Springer Nature remains neutral with regard to jurisdictional claims in published maps and institutional affiliations. 